\title{
Trade Union Transformation and Informal Sector Organising in Uganda: The Prospects and Challenges for Promoting Labour-led Development
}

\author{
Tobias G. Schminke and Gavin Fridell, St Mary's University, Canada
}

\begin{abstract}
Despite celebrations from governments, corporations and international financial institutions around increasing economic growth, the majority of the world's urban labour force continues to work under informal conditions, lacking enforceable contracts, adequate earnings, democratic representation, secure employment and social protection. The pervasiveness of informal labour globally has given rise to numerous calls to adopt a wider and more diverse understanding of what constitutes labouring classes and what is required to organise them. Our case study assesses the outcomes and effectiveness of informal sector organising in Uganda, focusing on the transportation, market and textile sectors. Drawing on Guy Standing's distinction between "business" and "community" unions and Benjamin Selwyn's contrasting of "capital-centred development theory" (CCDT) and "labour-led development" (LLD), we argue that community unionist approaches are most effective in addressing the decent work deficit in the informal economy. Simultaneously, the trade unions face constant barriers to successful community organising in the informal economy that cannot be easily overcome without wider changes to the structural conditions under which union organisers must operate.
\end{abstract}

\section{KEYWORDS}

Trade unionism; informal labour organising; labour-centred development; Uganda; decent work

Economic growth and an increase in global trade, investment and financial flows since the 1980s have led to an unprecedented accumulation of wealth alongside growing inequality and varied impacts on most populations in developing countries. While some states, in particular Asian economies, have experienced rapid economic growth combined with improved social indicators, others have experienced limited or worse results in comparison (Milberg and Winkler, 2010; Rosnick, Weisbrot and Wilson, 2017). Global value chain integration continues to be the dominant development mantra among international financial institutions. However, enthusiasm has been tempered by recognising that economic success in value chain integration does not necessarily lead to improved social outcomes, such as enhanced employment, better working conditions, gender equality, skills upgrading and poverty reduction (Barrientos, Gereffi and Rossi, 2010; Mayer and Pickles, 2010; Bamber and Staritz, 2016). Despite economic growth, the majority of the population in most developing countries continue to labour in the absence of what the International Labour Organization (ILO) terms "decent work", lacking enforceable contracts, adequate earnings, productive work, secure employment and social protection. This situation is widespread and especially prevalent in the informal economy, which employed around 61.2 per cent of the active global labour force outside the agricultural sector in 2017 (ILO, 2018: 13). In developing countries, 
this share is even higher, particularly in Eastern Africa. According to ILO (2018: 91) estimates, the share of informal workers among the total non-agrarian active labour force in 2017 ranged from 87.9 per cent in Zambia to 93.7 per cent in Uganda.

The precarious situation of informal labour has led to new initiatives, generally managed by formal sector trade unions, aimed at designing flexible and creative ways to organise the informal sector. While a range of relevant research has been conducted on the topic, most of it has focused on technical organising methods and apolitical barriers. The challenging nature of informal sector organising is emphasised, while the broader political economy that produces and reproduces the barriers to organising the informal economy is often overlooked or taken as given. There is also limited empirical research on informal sector union organising in East Africa generally, despite its pervasiveness (Spooner and Mwanika, 2016). In Uganda, informal work is dominant in the economy, and trade unions have been organising informal workers for over fifteen years. Simultaneously, it remains unclear how trade unions manage or fail to address the economic and political context of the decent work deficit in the informal economy, and what lessons there are to learn from their experiences.

In this article, we will assess the outcomes and effectiveness of informal sector union organising in Uganda, drawing on case study research in the transportation, market and textile sectors. The qualitative research is based on a cross-sectional study design with data triangulation to ensure the validity of the information collected (Berg, 2004: 4-5). The triangulation involved an intensive review of secondary data along with open-ended qualitative group and individual interviews with twelve trade union leaders, fifty-six workers, five key informants (academics, workers in non-governmental organisations [NGOs] and labour activists), and fourteen workplace observations between 7 and 25 March 2019. A majority of the workers interviewed were union members active in the informal economy; others had not signed up for union membership. The high number and variety of interview partners enhanced the verification of data. In Uganda's political environment, which is generally hostile to trade unions, it was essential to validate the information collected and not rely only on the views of high-ranking labour leaders or government members. Workers not organised in trade unions provided information on why they have not joined the union, revealing data on what thresholds trade unions face in the informal economy. The researcher selected trade union and trade union centre leaders with low and high engagement levels in the informal economy to learn more about the various thresholds trade unions face at different stages of the organising process. The trade union leaders gave insights on organising strategies that ultimately tie back to ideas around labour-led development (LLD) as well as business and community unionism. Informal workers organised in unions as part of a convenience sample offered insights at their workplaces or trade union meetings into what benefits they draw from the union. Interviews were conducted with individuals or groups of workers in safe spaces such as the trade union centre or in other mutually agreed locations. Additionally, workplace observations were used to get a comprehensive understanding of the workplace situation of the workers.

Drawing on Guy Standing's (1997) distinction between "business" and "community" unionism and Benjamin Selwyn's (2017) contrasting of capital-centred development theory (CCDT) and labour-led development, we explore the tensions between structure and agency, locating informal union organising in Uganda within the political economy of national and global markets. We argue that informal trade union organising in Uganda has been most effective when adopting a community unionist approach, pursuing LLD and attaining gains in social reproduction not traditionally understood as belonging to conventional union activities. At the same time, trade unions face considerable hurdles to overcoming structural barriers, reflected in constant tension with business unionism. On the one hand, antagonisms between community and business 
approaches limit what informal unions can accomplish. On the other hand, the possible benefits of business unionism - in particular, consistent dues, membership and funding - and their lack in the informal economy place constant barriers on the ability of unions to substantially address the concerns of informal workers. The result is a perpetual tension between business and community unionist strategies, which trade unions struggle to overcome. The first part of the article explores the tensions of informal sector union organising, followed by the Ugandan case studies and the lessons learned.

\section{Tensions in Informal Sector Unionism}

We are particularly concerned with the tensions inherent in informal sector union work between what Standing (1997) refers to as business unionism and community unionism. Business unionism refers to an apolitical "servicing model" of trade union organising that focuses on the shop floor and workers in an employee-employer relationship. It can be efficient at negotiating wages and working conditions requiring relatively limited resources and is managed by a technical bureaucracy. At the same time, it can lead to insider-outsider dynamics, where the union becomes focused on the needs of a relatively better off core constituency while neglecting the wider peripheral constituency, from which it becomes increasingly disconnected, unable to mobilise or represent in times of struggle or conflict (Standing, 1997; Hyman, 2001; Lindbeck and Snower, 2001; Linders and Kalander, 2010; Lindell, 2011). The opposite of this is community unionism, which Standing envisions as representing the labouring classes at large, concerned not only with collective bargaining but wider political and social struggles against government and capital to attain more for all workers. This approach would seem more compatible with the needs of informal workers, who often do not have formal employers to bargain with and who confront manifold challenges outside of typical labour-employer issues (Standing, 1997; Andrae and Beckman, 2011; Lindell, 2011). It also addresses the needs of the labour movement as a whole, providing solidarity to limit the ability of employers to play formal workers off against the unemployed or underemployed, whom Marx famously referred to as the "reserve army of labour" (Marx, 1867: 623-633; Amin, 1976: 351-364; Swaminathan, 1991; Faniel, 2009). And yet, while conceptually community unionism might seem more compatible with informal sector organising, in practice business unionist strategies are widespread. Rather than seeing the two forms of unionism as distinct spheres, it is more effective to see them as dialectically engaged, with social and political pressures pushing union organisers in different directions, reflecting a tension between the two styles. We explore this dynamic, drawing predominantly on three bodies of work.

First, to assess the impact of informal sector organising, we draw on the ILO's (2019) decent work agenda. This widely used framework involves eleven measurable indicators, defining decent work as including: employment opportunities; adequate earnings and productive work; decent working time; combining work, family and personal life; eliminating work that should be abolished; stability and security of work; equal opportunity and treatment; safe work environment; social security provision; social dialogue through workers' and employers' representation; and providing the economic and social context for decent work. Meeting these criteria can be difficult for formal, organised workers, and, as the ILO acknowledges, is extremely difficult for informal workers, who lack access to various political, economic and social resources (Chen et al., 2005; Verick, 2006; ILO, 2002, 2018).

While the ILO offers criteria for mapping labour conditions, the decent work agenda is primarily technical and descriptive. It tells us little about how to achieve decent work, why informal 
work persists and whose interests it serves (Sehnbruch et al., 2015: 200; Selwyn, 2017: 89-92). This gap leads to the second body of work, the structuralist school, which seeks to account for and explain the persistence and growth of informal employment. The structuralist school on the informal economy, which evolved in the 1980s, pointed out that the informal sector is an integral part of global capitalism through two dynamics. First, the informal economy benefits capital that seeks cheap and flexible labour. Second, governments are interested in providing conditions attractive to foreign investment, leading to tax income and foreign currency reserves. Structuralists concluded that decent work policies tend to come about only when organised labour pressures government and industry to go against their own, immediate interests (Portes and Sassen-Koob, 1987; Gallin, 2001; Mosoetsa, 2001; Haller and Portes, 2005).

Moreover, structuralist thinkers expand the definition of informal workers to include not just those in an employee-employer relationship but also casual wage workers, home-based workers and self-employed workers (Harding and Jenkins, 1989; Hussmanns, 2004; Pearson, 2004; Chen, 2012; Chen, Bonner and Carré, 2015). This broader definition exposes the impact of informal employment on global and local supply chains. Informal street collectors, for example, supply formal recycling factories, and formal haulage companies transport goods for formal international companies while employing informal workers. The more expansive definition advanced by structuralist thinkers encompasses these workers and, importantly, views them as targets for union organising (Portes and Sassen-Koob, 1987: 38).

The broad definition of informal work links to the work by Benjamin Selwyn $(2014,2017)$ on labour-centred development (LCD), the third body of work that we draw upon. Selwyn (2017) argues that mainstream development thinking, such as neo-liberalism and statist thinking, can be categorised as capital-centred development theory, which is characterised by three consistent themes. First, CCDT sees capital accumulation as the basis for development. Second, CCDT views genuine development visions as emerging from paternalistic guidance from "elite" experts, such as corporations, state planners or NGOs. Third, CCDT sees the labouring classes as passive objects who lack primary agency in achieving and defining development on their own. Instead, it often depicts the struggles of the poor for improved living conditions as a barrier to development - for instance, when popular struggles block roads, obstructing the free flow of goods. CCDT then often points at these struggles and uses them to directly or indirectly justify elite repression and continued exploitation while assigning to the poor secondary - but never primary - agency for development. Selwyn argues that the development model promoted by CCDT experts cannot explain or confront the power relations between labour, capital and the state. Hence, CCDT leads to minor political reforms that greatly prioritise the demands of global capital over the urgent everyday needs of labouring classes. The only way out of this trap is for labouring classes to organise and struggle as primary agents for development for themselves (Selwyn, 2017: 92).

Selwyn argues for a broad vision of LCD which can involve three main sub-processes: 1) prolabour development, wherein "enlightened elite policies" from the state benefit workers and support labour activity; 2) labour-driven development, where workers act collectively to make demands and attain concessions from the state and capital (such as welfare state reforms); and 3) labour-led development (LLD), involving a "process where labouring-class collective actions directly generate meaningful improvements to their and their communities' livelihoods" (Selwyn, 2017: 10-11, emphasis in original). He is most concerned to promote labour-led development as the most substantive challenge to CCDT. LLD involves many components, the most significant of which, for our analysis here, entails four considerations. First, LLD looks at development "from the vantage point of labour", which entails a focus not on the goal of capital accumulation (the "vantage point of capital") but on increased wages and improved ability of workers to sustain themselves and meet 
their own defined needs (Selwyn, 2017: 102-105). Second, meeting workers' needs involves a range of social reproductive necessities outside the immediate interests of capital, even while capital plays the defining role in determining their form. This includes not only higher wages and decent work, but a range of issues from easing the social reproduction of labour (through, for example, public childcare), promoting gender and racial equality, or safe and secure access to a range of activities (employment, education) and resources (land, water, housing) (Selwyn, 2017: 105). Third, and connected to the previous two, this entails a broad definition of "labouring classes" that includes a range of workers - including unpaid women workers, urban and rural employed and unemployed, informal workers, small-scale peasants and emerging middle-class workers. All of these groups have diverse needs and demands, even while capital and the state remain the greatest barrier to obtaining them (Selwyn, 2017: 15-19). Finally, given Selwyn's (2017: 11) focus on agency, LLD can be assessed not only for what it attains but also for creating a space for "democratic ends", where political, economic and cultural participation in institutions and decision-making are goals that are "developmental in and of themselves".

Structuralist works and the LCD approach point not only to the agency of labouring classes but to the powerful structural imperatives they face. In this case, informal workers confront the demands of everyday survival, limited resources, oppressive states, global and local market imperatives, tensions between formal and informal workers over resources and organising priorities, and the power of transnational capital that assertively resists formalising and improving labouring conditions for the sake of corporate profitability (Lindell, 2011; Schuman and Eaton, 2013; Chen et al., Carré, 2015). The agency of informal workers is constrained and shaped by the very structural conditions they face (Selwyn, 2017:122-123). These external factors lead to tensions not only outside of labour organizations - between capital and labour - but within them as organisations themselves shift between CCDT and LLD visions. These tensions play out in struggles over pursuing a more business unionist approach, or carving out spaces for a more community unionist approach focused on a range of political and social struggles and activities outside the boundaries of CCDT-defined employment relations. We argue that informal trade union organising in Uganda has been most effective when it adopted a community unionist approach that includes addressing workers' issues beyond the shop floor in line with LLD thinking. Concrete examples are blocking the privatisation of public lands, providing an autonomous space to exchange ideas under authoritarian political conditions, creating union-owned apps to compete with corporate ones, providing credit and daycare services, and offering training around safety and HIV/AIDS. The ability of unions to conduct these activities, however, is in constant tension with business unionism on two fronts. First, business unionist tensions within unions place barriers on what they can accomplish (in particular, unease among formal workers over their membership dues spent on informal worker activities). Second, the lack of a more formal structure, based on steady dues, a consistent workforce and a relatively well-funded bureaucracy (along the lines of traditional business unionist thinking) places constant barriers on the ability of unions to substantially address the concerns and needs of informal workers in a steady and reliable way.

\section{Union Organising in Uganda}

Research on informal sector organising is particularly relevant in Uganda, where over 90 per cent of workers are informal, social protection covers only 2 per cent of the workforce (Ulandssekretariatet, 2016: 18), and union centres and their affiliated trade unions formally represent less than 5 per cent of the total workforce. Moreover, the International Trade Union 
Confederation (ITUC, 2012) reports that violent oppression by government and enterprises impedes trade union organising, which can be traced back to pre-independence Uganda. At the time, the colonial government deported trade union leaders, de facto banned strikes and promoted enterprise-level staff associations that neglected the broader political goals of labour (Barya, 1990: 77; IFPTE, 2019). Continued government oppression after independence was coupled with apolitical and business unionist education by Western trade unionists of the British Trades Union Congress (TUC) and the International Confederation of Free Trade Unions (ICFTU) (Barya, 1990: 178-263). In 1996, incumbent President Yoweri Museveni - after implementing a series of neoliberal reforms prescribed by the Bretton Woods institutions - established the workers' MP-system, which allocates five out of 426 seats in the national parliament for workers elected by an electoral college of unionised workers. Key informants during this research argued that trade union leaders often rely on workers' Members of Parliament to publicly voice their political concerns, despite their numerical insignificance in parliament (Interview XVI, Key Informant). Moreover, the 2006 Labour Union Act refers to workers with the right to organise as "employees ... under a contract of service". This framing excludes many informal economy workers who do not have a contract and are self-employed or own-account workers. This legal uncertainty is a challenge for trade union organising because it discourages unions from interacting with informal workers (Interview VIII, Trade Union Leader; Interview XV, Trade Union Leader).

Colonial and post-colonial labour legislation and decades of political oppression and cooptation have placed severe barriers on labour mobilisation beyond the shop floor. Under these conditions, unions tend to view themselves as first and foremost responsible for their core constituency - the workers they already organise - and not peripheral constituencies like informal workers. Business unionism tends to dominate. At the same time, the government de facto tolerates the organisation of non-employee workers into trade unions (Interview VIII, Trade Union Leader). And, given the overwhelming preponderance of informal workers in the Ugandan economy, some unions have pushed beyond the boundaries of formal union organising, launching various initiatives to organise informal workers.

\section{Trade union organising in Uganda's informal transport, market and textile sectors}

At the time of the interviews in March 2019, eleven out of forty-four unions in Uganda serviced the informal economy. Nine of these unions were affiliated with the National Organisation of Trade Unions (NOTU), the largest trade union confederation in the country (which claims 927799 members). Two were affiliated with the Central Organisation of Free Trade Unions (COFTU), the second-largest (which claims 432800 members). This research selected five unions from the three sectors with the most vital informal worker organising activities (see Table 1). Beyond these, the National Trade Union of Theatrical, Domestic and General Workers (17 500 members), the National Union of Creative, Performing Artists and Allied Workers (755 members), the National Union of Plantation and Agricultural Work (120 000 members), the Uganda Fisheries and Allied Workers Union (1 500 members), the Uganda Horticulture, Industrial Service Providers and Allied Workers Union (1 000 members), the Uganda Hotels, Food, Tourism and Allied Workers Union (HTS Union) (50 000 members), and the Uganda Hospitality, Leisure and Allied Workers Union (32 members) are all affiliated with NOTU and at least do some organising among informal workers (Interview V, Trade Union Centre).

Key informants underlined that other trade unions did not engage with the informal economy and explained this by saying that some union leaders were primarily interested in the personal income opportunities the union generates for themselves. These union leaders cater - in a business 
unionist spirit - to a small, formal workforce, which is satisfied with and supportive of the union leadership as long as it delivers wage increases and better working conditions through collective bargaining (Interview XVI, Key Informant). In cases where union leaders devote resources toward the difficult-to-organise informal economy, their position can be challenging. It is essential for democratically elected leaders, who seek re-election, to ensure that their primary electorate, the formal workers, do not feel ignored or sidelined (Interview I, Trade Union Leader). Despite this potential risk, some union leaders have started organising the informal economy. In interviews they stated that it is their call to improve the situation of the labour movement, anticipating positive outcomes for all workers if they organise the informal economy. In other cases, trade union leaders might also be motivated because they can grow their organisation's power if they can increase the numbers behind them. This thinking has, in some cases, led to influential unions successfully organising the informal economy, which is especially the case for Uganda's transport sector.

Table 1. Trade unions in Uganda included in the research

\begin{tabular}{|l|l|l|l|l|l|}
\hline Union & ATGWU & NUDIKAWA & $\begin{array}{l}\text { Market } \\
\text { Union }\end{array}$ & $\begin{array}{l}\text { Market } \\
\text { Union }\end{array}$ & UTGLAWU \\
\hline Sector & Transport & Transport & $\begin{array}{l}\text { Food and } \\
\text { textile retail } \\
\text { markets }\end{array}$ & $\begin{array}{l}\text { Food and } \\
\text { textile retail } \\
\text { markets }\end{array}$ & $\begin{array}{l}\text { Textile } \\
\text { (leather) }\end{array}$ \\
\hline TU Centre & NOTU & COFTU & NOTU & COFTU & NOTU \\
\hline Membership & 101350 & 10000 & 4000 & n.a. & 5771 \\
\hline Legal status & $\begin{array}{l}\text { Formal and } \\
\text { informal }\end{array}$ & $\begin{array}{l}\text { Formal and } \\
\text { informal }\end{array}$ & Informal & Informal & $\begin{array}{l}\text { Formal and } \\
\text { informal }\end{array}$ \\
\hline $\begin{array}{l}\text { Employment } \\
\text { status }\end{array}$ & $\begin{array}{l}\text { Employees, } \\
\text { self-employed }\end{array}$ & $\begin{array}{l}\text { Employees, } \\
\text { self-employed }\end{array}$ & $\begin{array}{l}\text { Employees, } \\
\text { self-employed }\end{array}$ & $\begin{array}{l}\text { Employees, } \\
\text { self-employed }\end{array}$ & Employees \\
\hline $\begin{array}{l}\text { Dominant } \\
\text { gender }\end{array}$ & Men & Men & Women & Women & Mixed \\
\hline
\end{tabular}

ATGWU = Amalgamated Transport and General Workers' Union

NUDIKAWA = National Union of Drivers, Cyclists and Allied Workers

UTGLAWU = Uganda Textile, Garment, Leather and Allied Workers' Union

\section{Trade union organising in Uganda's informal transport sector}

In 2003, the Amalgamated Transport and General Workers' Union (ATGWU) was a business union focused on the shop floor and its core constituency; it organised 5000 formal workers in a few enterprises. At the time of the field research, ATGWU had around 100000 members, of which 80000 were informal workers organised in eleven workers' associations. ${ }^{1}$ Most of the affiliated associations only joined after leadership changes within ATGWU in the early 2010s, which opened the trade union to the idea of informal worker organising on a larger scale. The decline in formal sector work, caused by newly introduced neo-liberal labour laws and a general lack of labour law enforcement, contributed to this strategic shift (Interview I, Trade Union Leader).

ATGWU has addressed multiple dimensions of the decent work deficit among informal

\footnotetext{
${ }^{1}$ A workers' association manages a workplace in the informal economy to ensure that conflicts between workers and with customers, management or local government are avoided or solved. They engage in collective representation with outside organisations on behalf of the workers they organise in one workplace.
} 
workers in the transport sector, which can be related to the ideas around LLD and community unionism (see Table 2). Ugandan workers' associations outside of trade unions often maintain informal connections with President Museveni's entourage and the Ugandan government party, the National Resistance Movement (NRM). These connections can involve bribery and depend on the goodwill of their counterparts. Associations stated that they ended this dependence without losing influence by affiliating with the union, claiming that ATGWU now represents their interests in the political discourse (Interview XI, Trade Union Leader). One of the gains that ATGWU has achieved as an independent union has been to protect informal workers from the privatisation of public land, which serves as a workplace for transport workers. The Kampala City Council Authority (KCCA) intended to privatise minibus or taxi ${ }^{2}$ parks in Kampala, which made the transportation workers fear that they would be vulnerable to higher rents for parking spaces imposed by new private owners. ATGWU pressured the KCCA to stop the privatisation, successfully threatening the city government with strikes (Interview X, Worker). One could argue that - in line with LLD - the union met the workers' needs outside of the immediate interests of capital. Halting privatisation through the collective power of the union could, even in settings outside of the workplace, show a pathway to a situation where, as (Selwyn, 2017: 10-11) puts it, "labouring-class collective actions directly generate meaningful improvements to their and their communities' livelihoods".

ATGWU also collectively negotiated between informal taxi drivers and the aviation authority at Entebbe International Airport in 2008. After years of conflict between the informal drivers and airport management, ATGWU successfully demanded parking and office space inside the airport for the informal cab drivers, organised in the AirPort Taxi Services Co-operation Society Limited (Interview I, Trade Union Leader). Some workers from the craft traders and producers' association, Tukulerewamu, which is also affiliated with ATGWU, reported similar instances in which the union helped secure workspaces against the government's interest and powerful private actors. One worker reported a conflict with the city government over market space:

In the market, we were working, but they were chasing us - the KCCA - without giving us notice. Someone told us that there is a trade union, so we joined their office. By the time we joined the office, the trade union stood up, came in and talked to the landlord and KCCA. Then afterwards we got our working place. Before the union, we were working looking side by side that [the KCCA was] not chasing us (Interview X, Worker).

In other cases, ATGWU organised volunteer workers from the HIV/AIDS survivors' Galima Fights HIV/AIDS Initiative (Galima) (Interview X, Worker; Interview XI, Trade Union Leader). The actions of Galima and the union go beyond collective bargaining-focused business unionism: they also educate truck drivers about HIV/AIDS, since many of them are prone to engage in sexual activities with risk groups, such as prostitutes, while away from home (Interview X, Worker; Interview XI, Trade Union Leader). Additionally, interviewees revealed that ATGWU helped address employment security concerns: informal long-distance truck drivers in Uganda work for international haulage companies that usually do not provide written employment contracts. Leaders of the ATGWU reported that the transport enterprises hire and fire the informal workers as they wish. In some instances, haulage companies sacked lorry drivers on their way back to the transport enterprise after delivering the goods, without paying the workers. The union often found out that the employees were not aware of the employer's existing legal obligations. In response, ATGWU

\footnotetext{
${ }^{2}$ Minibuses in Uganda are called taxis; passenger cars for hire are referred to as cabs.
} 
initiated an education campaign around the need for workers to obtain a written work contract and their rights when in conflict with their employers (Interview XI, Trade Union Leader). Beyond this campaign, workers often received training on leadership, negotiation, bargaining and presentation skills by ATGWU. The informal workers welcomed these initiatives, hoping that these skills would improve their ability to negotiate with landlords or local governments.

Table 2. How trade unions in Uganda's informal transport sector address decent work

\begin{tabular}{|c|c|c|}
\hline & ATGWU & NUDIKAWA \\
\hline $\begin{array}{l}\text { Employment } \\
\text { opportunities }\end{array}$ & $\begin{array}{l}\text { Organised rallies against the } \\
\text { privatisation of taxi parks }\end{array}$ & - \\
\hline $\begin{array}{l}\text { Adequate earning and } \\
\text { productive work }\end{array}$ & $\begin{array}{l}\text { Created trade-union-owned hiring } \\
\text { mobile app to avoid exploitation of } \\
\text { the drivers by companies; prevents } \\
\text { theft of goods by government } \\
\text { workers }\end{array}$ & $\begin{array}{l}\text { Critiques wages and working } \\
\text { conditions of private hiring mobile } \\
\text { apps }\end{array}$ \\
\hline $\begin{array}{l}\text { Stability and security } \\
\text { of work }\end{array}$ & $\begin{array}{l}\text { Secured workspace for } \\
\text { Tukulerewamu workers through } \\
\text { negotiations with investors and the } \\
\text { city government }\end{array}$ & - \\
\hline $\begin{array}{l}\text { Equal opportunities } \\
\text { and treatment in } \\
\text { employment }\end{array}$ & - & $\begin{array}{l}\text { Files petitions regarding discrimin- } \\
\text { ation against Ugandan informal } \\
\text { transport workers in Tanzania }\end{array}$ \\
\hline $\begin{array}{l}\text { Safe work } \\
\text { environment }\end{array}$ & $\begin{array}{l}\text { Trains workers on substandard (or } \\
\text { complete lack of) safety gear and } \\
\text { HIV/AIDS }\end{array}$ & $\begin{array}{l}\text { Lobbies with the government for } \\
\text { more reliable traffic infrastructure }\end{array}$ \\
\hline Social security & $\begin{array}{l}\text { Educates workers about the need for } \\
\text { written work contracts and legal } \\
\text { rights for workers }\end{array}$ & $\begin{array}{l}\text { Pressures employers to provide } \\
\text { workplace accident compensation and } \\
\text { written work contracts }\end{array}$ \\
\hline $\begin{array}{l}\text { Social dialogue, } \\
\text { workers' and } \\
\text { employers' } \\
\text { representation }\end{array}$ & $\begin{array}{l}\text { Campaigns to end precarious } \\
\text { patronage bondage between workers' } \\
\text { associations and corrupt government } \\
\text { officials; provides political space in } \\
\text { authoritarian political environment }\end{array}$ & $\begin{array}{l}\text { Conducts radio education } \\
\text { programmes to educate informal } \\
\text { workers on their right of association }\end{array}$ \\
\hline $\begin{array}{l}\text { Economic and social } \\
\text { context for decent } \\
\text { work }\end{array}$ & $\begin{array}{l}\text { Negotiates with government to } \\
\text { improve laws and regulations; } \\
\text { provides training on leadership, } \\
\text { negotiation, bargaining and } \\
\text { presentation skills }\end{array}$ & - \\
\hline Barriers & $\begin{array}{l}2006 \text { Labour Union Act; workers } \\
\text { frequently change their workplace; } \\
\text { workers leave union after short } \\
\text { period; workers do not have the } \\
\text { necessary time and income for active } \\
\text { trade union membership; low level of } \\
\text { representation of informal workers in } \\
\text { trade union leadership; informal- } \\
\text { formal workers divide within trade } \\
\text { union }\end{array}$ & $\begin{array}{l}2006 \text { Labour Union Act; workers } \\
\text { change workplace frequently }\end{array}$ \\
\hline
\end{tabular}

ATGWU = Amalgamated Transport and General Workers' Union

NUDIKAWA = National Union of Drivers, Cyclists and Allied Workers 
The ATGWU workers emphasised in the interviews that membership in the trade union secures the right of assembly for the workers, which the Ugandan government generally curtails for the rest of the population. The Public Order Management Act 2013, which was in place during the research, exempts trade unions and affiliated associations - including ATGWU members from the requirement to inform the police if more than ten people meet. Informal workers emphasised in group interviews that the union provides an open platform for exchanging ideas (Interview IX, Worker). Protecting this potential political space for workers is a substantial achievement in an otherwise authoritarian political climate and adds another layer to ATGWU's community unionist activity, creating a space for "democratic ends", where political, economic and cultural participation in institutions and decision-making are goals that are "developmental in and of themselves" (Selwyn, 2017: 11).

Despite its achievements, ATWGU faces many problems in organising informal workers, particularly in cases where more than one leadership group claims to represent the same workers, leading to conflict and strife. Furthermore, the leadership of individual unions and trade union centres did not, at the time of the research, have a proportionate number of informal workers in its ranks. NOTU representatives, for instance, admitted in interviews that the integration of informal workers into the leadership structure of the labour movement poses a challenge. They asserted that informal workers were not yet sufficiently skilled to take up leadership positions. Only five out of twenty-four NOTU executive board members elected in the 2018 leadership vote came from the informal economy, although half of NOTU's membership is from the informal economy (Interview I, Trade Union Leader). Also, ATGWU leaders reported that there were challenges related to convincing informal workers to remain within the union for an extended period. In cases where unions provided such services as saving schemes, informal workers often joined to access loans, paying membership dues only until they obtained their credit (Interview VIII, Trade Union Leader). This lack of a stable membership base hints at the challenges facing trade unions, which go beyond shop-floor-focused business unionist organising and engage in more community unionist activities in the informal economy.

The National Union of Drivers, Cyclists and Allied Workers (NUDIKAWA) is ATGWU's counterpart, organised under the smaller trade union centre COFTU; it claimed 10000 dues-paying formal and informal sector members in March 2019. The union has mainly focused on launching formal complaints to lawmakers and the government about unsatisfactory working conditions experienced by informal workers, particularly the low wages and poor working conditions of those working with Taxify, Uber and other private hiring apps (Interview XXIV, Trade Union Leader). ATGWU has gone further, creating a union-owned app called the KAMBE app. The app pairs drivers with customers but, unlike Taxify and Uber, does not deduct a share from the driver's salary for the profits of the app provider. The app also offers an option to participate in individual or collective savings, which can be critical to drivers who often cannot save in a bank because they lack income, formal addresses and legal work contracts. ATGWU's efforts underline how the union offers innovative community unionist ways of organising.

Discussing the challenges faced by informal transport workers, the NUDIKAWA leadership reported that it is challenging for unions to find space and time to recruit, inform or train informal workers for union activities. They explained that this situation exists because informal workers constantly search for customers and income, and many change their workplaces regularly. To address this, NUDIKAWA has turned to radio programmes for information dissemination. Each episode educates workers about their labour rights and NUDIKAWA's trade union activities (Interview XXIV, Trade Union Leader). ATGWU leaders, for their part, conveyed a sense of unease from some formal workers who had the impression that the trade union allocated resources 
created through their membership dues toward informal newcomers. These tensions hint at hurdles trade unions confront between business and community unionist approaches. Trade union leadership candidates have tried to exploit this informal-formal division in the past during trade union leadership elections. ATGWU has attempted to address this challenge through additional communication efforts, training and more financial transparency. One informal transport worker stated during the interviews:

After joining ATGWU, whether you are formal or informal, the training of ATGWU has told us that we are all equal. When we are equal, everything is run smoothly. Whether you come with your degrees, from me, I have no A-Level certificate; I can lead you. We are all equal (Interview IX, Worker).

\section{Trade union organising in Uganda's informal market sector}

Uganda's market sector - which in this context refers to retail markets that predominantly sell perishable goods and clothes to consumers - shows the internal organisational challenges and external hardships unions and workers face when organising. Almost all unions operating in this sector exclusively organise informal workers (Interview III, Trade Union Leader; Interview VIII, Trade Union Leader). The workers in the trade union are predominantly self-employed, ownaccount workers and employees at the market. Market workers generally have difficulty accessing bank accounts and loans (Interview XXV, Worker), making it challenging to expand businesses or finance personal investments such as housing or a motorised vehicle.

One of the market unions claims to provide affordable access to credit for informal workers through collective savings (Interview VIII, Trade Union Leader). The union also facilitates visits from doctors who inspect workplaces and perform disease treatment without charge (see Table 3). This service is significant as many market workers cannot afford the fees charged in public and private healthcare facilities (Interview XXV, Worker). Key informants, however, maintained that it is unclear to what extent the union provides the services it claims to. Reflecting the complex nature of union politics in Uganda, they stated that the union leader is also the owner of multiple stores and serves as a Presidential advisor (Interview VI, Key Informant). None of the nonunionised workers interviewed at the market knew about the union's existence, but all workers interviewed knew the union leader's name. Some of them suffered life-threatening injuries from attacks, including sexual assault and theft, which they believe were orchestrated by the union leader. They reported that a SACCO ${ }^{3}$ managed by that person, worth millions of US dollars, disappeared overnight. The workers had organised in an association and had backed up their claims with a 157page document in which they provided evidence for an associated ongoing court case. Poor leadership and a lack of democracy in some of the market trade unions, as attested by key informants and workers, leaves space for corrupt officials, management and the government to use union structures to access funding for personal enrichment (Interview XXVII, Worker).

Another market union organises exclusively informal workers, predominantly through SACCOs (Interview III, Trade Union Leader; Interview VIII, Trade Union Leader). The union members are market stall owners, market employees, workers who transport market goods and street vendors (Interview VIII, Trade Union Leader). Union leaders reported that the union's main

\footnotetext{
${ }^{3}$ SACCO stands for Savings and Credit Cooperative Society. A SACCO is a collective saving and lending institution established and run by informal workers on the local level. If workers contribute on a regular basis, they are able to access loans which they can use for investments in their businesses or for personal expenses.
} 
challenge when organising the informal economy is a lack of income (Interview VI, Key Informant; Interview VIII, Trade Union Leader). They reported that it is difficult to access international funding due to a highly competitive environment, while at the same time members or associations are not providing regular contributions due to their low and irregular incomes, a situation which is dominant in the informal economy (Interview III, Trade Union Leader; Interview VI, Key Informant). The example underlines the thresholds to community unionist organising that cannot rely on formal employees' regular contributions. Market workers set up SACCOs, but union leaders argued that the capacity of these member-funded financial instruments is too limited to address the decent work deficits of market workers. The market union members raised concerns about child labour, a lack of health and business insurance against frequent fires that destroy goods and stalls, a lack of proper cooling storage facilities, and a lack of occupational health and safety measures. They also alluded to the weak drainage systems and lack of waste management, which caused waste to float around in the market, causing diseases. The workers expect their union to address a range of social reproductive necessities outside the immediate interests of capital, which the union has been able to do (through SACCOs and providing basic training in safe work and HIV/AIDS) - although in a tightly constrained way due to lack of funds and resources. Workers also emphasised that inner-union democracy provides a governance structure that allows them to choose their leadership, which can represent them when dealing with local government.

Table 3. Trade unions in Uganda's informal market sector addressing decent work

\begin{tabular}{|l|l|l|}
\hline & Market Union 1 & Market Union 2 \\
\hline $\begin{array}{l}\text { Adequate earning and } \\
\text { productive work }\end{array}$ & $\begin{array}{l}\text { Provides collective saving } \\
\text { opportunities }\end{array}$ & - \\
\hline $\begin{array}{l}\text { Combining work, family } \\
\text { and personal life }\end{array}$ & $\begin{array}{l}\text { Provides trade-union owned } \\
\text { daycare centre }\end{array}$ & Facilitates free doctors \\
\hline $\begin{array}{l}\text { Eafe work environment } \\
\text { context for decent work }\end{array}$ & $\begin{array}{l}\text { Educates employees and employers } \\
\text { about existing labour laws }\end{array}$ & $\begin{array}{l}\text { Represents workers against local } \\
\text { governments; union conducted } \\
\text { training for workers on leadership, } \\
\text { business and financial management }\end{array}$ \\
\hline Barriers & $\begin{array}{l}\text { Authoritarian government and } \\
\text { influential capital with control over } \\
\text { trade union; weak democracy } \\
\text { within the trade union; limited } \\
\text { (financial) power of workers to } \\
\text { legally fight powerful actors in } \\
\text { authoritarian and corrupt } \\
\text { environment; 2006 Labour Union } \\
\text { Act }\end{array}$ & $\begin{array}{l}\text { Unions underfunded due to } \\
\text { informal workers' low and irregular } \\
\text { incomes; low income of workers' } \\
\text { representatives makes them } \\
\text { vulnerable to corruption; 2006 } \\
\text { Labour Union Act; lack of } \\
\text { knowledge about trade unionism } \\
\text { among workers }\end{array}$ \\
\hline
\end{tabular}

The union in this context is able to attain its greatest gains when it ventures outside of an approach that is strictly focused on shop-floor, business unionism and adopts a more community unionist approach. Overall, however, informal workers and key informants expressed concerns about the national government, political parties and private actors corrupting union leadership, 
spurred on by the fact that the unions generated little income to affirm their independence and conduct activities on their own. As the number of registered unions in Uganda has declined over the past forty years, most remaining unions service only a small share of the population. In the market, it was rare to find workers, organised or not, with much to say about unions. Market workers have little income or time to explore or participate in union activities. Their precarious situation forces them to direct their time and energy toward daily survival (Interview III, Trade Union Leader).

\section{Trade union organising in Uganda's informal textile sector}

The Uganda Textile, Garment, Leather and Allied Workers' Union (UTGLAWU) is the only trade union in Uganda for textile workers. It claimed a membership of 5771 at the beginning of 2019 (Interview VII, Trade Union Leader). UTGLAWU started its activities in 2007, initially limiting its operations to casual employees in a leather factory in Jinja in Eastern Uganda (Interview VX, Trade Union Leader). The union has expanded geographically but has not shifted its strategy beyond the large-scale factories because formally self-employed textile workers usually work from home and are difficult to identify. One could argue that the union generally has only a thin community unionist culture, and instead focuses on the shop floor of selected core constituencies - that is, employees in employer-employee relationships in large factories rather than small-scale producers.

The textile industry is dominated by Chinese investors. Working conditions often do not comply with labour regulations and laws. For example, wages can be as low as 3000 UGX per day (US\$0.88) (Interview XXIX, Worker). Sexual violence and harassment are also common among the largely female workforce. In group interviews, women workers told stories of sexual assault and rape. Under management threats, women also feared becoming pregnant - whether from rape or consensual relations - turning to secret abortions to avoid dismissals.

Given that influential foreign investors own the factories, they have attained favour and support from the national government, which threatened union leaders and warned them against overt challenges to foreign owners. Despite these threats, informal workers report that UTGLAWU has sought to represent workers and pressure the company to meet basic standards (see Table 4). Workers report having been severely injured by the improper use of chemicals and machines. The union was able to pressure the company to pay compensation in one case where a workplace accident incapacitated an employee (Interview VII, Trade Union Leader; Interview XXIX, Worker). In another example, the union pressured employers to issue employee identity cards in English - instead of Chinese as it previously had - and written employment contracts, which give informal workers evidence of employment when dealing with local authorities or during legal disputes (Interview XXIX, Worker). Informal workers also reported that the employers used to cane workers, which stopped after the union threatened the managers with strikes (Interview VII, Trade Union Leader; Interview XXIX, Worker). As a result of the conditions faced by informal workers, substance abuse is high among them. The union seeks to address this abuse through sensitisation and education programmes (Interview VII, Trade Union Leader; Interview XXIX, Worker).

Despite efforts by UTGLAWU, workers continue to have highly precarious jobs, and employers hire and fire workers daily. Workers do not have any vacation days and can, during rush orders by international buyers, work up to fifteen hours a day with no break (Interview VII, Trade Union Leader). Given their low wages and precarious situation, many workers are hesitant to join the union and subsequently pay the associated fee. Outside of the factory gates, many issues remain unaddressed. For example, Leuenberger and Bachofen (2008: 91-92) report that the foreign leather companies drain toxic waste and by-products into nearby Lake Victoria instead of using the local 
waste management system. The alleged activities, echoed by local sources during the research, endanger millions of people who rely on the fresh water and fish provided by the lake. If the informal workers have lunch breaks, the managers only provide them with posho ${ }^{4}$ and beans. They drink untreated tap water, which in Jinja poses a significant health risk due to the level of pollution of the local water sources (Interview VII, Trade Union Leader; Interview XXIX, Worker). At the time of the field research, it was unclear how the union would address these unresolved issues. While lack of resources and an oppressive political context are major barriers to union action, at the same time the union lacks a robust community unionist culture that could help it address some of the issues that are not directly related to the shop floor and thus to expand its impact and presence.

Table 4. Trade unions in Uganda's informal textile sector addressing decent work

\begin{tabular}{|l|l|}
\hline Safe work environment & UTGLAWU \\
\hline Social security & $\begin{array}{l}\text { Reduces physical abuse by employers; education on occupational health } \\
\text { and safety targeting substance abuse }\end{array}$ \\
\hline $\begin{array}{l}\text { Social dialogue; workers' and } \\
\text { employers' representation }\end{array}$ & $\begin{array}{l}\text { Forces employers to provide workers with written employment } \\
\text { contracts in English }\end{array}$ \\
\hline Barriers & $\begin{array}{l}\text { Provides unionisation despite employer and government hostility to } \\
\text { workers' organisation }\end{array}$ \\
\hline $\begin{array}{l}\text { Authoritarian government and capital threaten workers and trade union } \\
\text { organisers; lack of community unionist culture to address issues outside } \\
\text { of the factory gates (focus on core constituency in large factories) }\end{array}$ \\
\hline
\end{tabular}

UTGLAWU = Uganda Textile, Garment, Leather and Allied Workers' Union

\section{Conclusion}

Despite the many challenges unions face, the Ugandan cases offer important lessons on how informal sector organising can contribute to the struggle to attain decent work in East Africa and across the Global South. These lessons must be situated within a recognition of the persistent structural barriers to organising within the informal sector and how these barriers lead to ongoing tensions between business and community unionist approaches. Our case studies reveal that a community unionist approach aimed at labour-led development offers the most effective way to attain tangible gains for informal labour. This involves adopting both a wider vision of who the labouring classes are - in this case, informal transport workers, self-employed own-account taxi drivers, contractual truck drivers, market workers, stall owners, street vendors and informal factory workers - and what the immediate goals and aims of organising should be. The latter includes a range of productive and social reproductive goals outside of formal employer-employee relations - blocking privatisation, defending secure workspaces, creating mobile apps to facilitate informal work, providing credit and daycare services, and offering training on safety, drug abuse and HIV/AIDS. In order to achieve success in these areas, it is necessary to create autonomous spaces for democratic engagement and dialogue among workers as goals "in and of themselves" (Selwyn, 2017: 11). AGTWU has perhaps been most successful in this regard, organising thousands of transport workers in struggles that have defended their right to employment opportunities and

\footnotetext{
${ }^{4}$ Posho is a stiff porridge made from (in this case) water, maize flour and a bit of salt.
} 
income, a more stable and secure environment, and enhanced leverage in social dialogue with government and the private sector. The key to their relative success has been a creative approach to organising beyond the confines of traditional business unionism.

Simultaneously, what informal organising has been able to accomplish has been constrained by the authoritarian political-economic context, and the general barriers to union organising encapsulated in ongoing tension with a business unionist approach. As anticipated by a business unionist framework, union leaders have had to carefully manage insider-outsider tensions, placing economic and political limits on how much effort and resources can be devoted to supporting the needs of informal workers. The insights from business unionism, however, are not strictly negative, as this approach also points to what an organisation needs to survive and expand under often hostile political-economic conditions. This includes a predictable membership, stable fees and funding, space, and time for organisation and engagement among workers and their leadership. At the union level, these factors have been predominant in limiting what organisers can accomplish. Thus, while community unionism reveals what can be accomplished through informal sector organising, using creative thinking to push the boundaries of labour rights and decent work, it is not clear how to push beyond these boundaries.

Selwyn (2017: 122) is aware of these challenges, recognising the vulnerabilities confronted by LLD, whose initial "dynamism" is often eroded by powerful capitalist structural barriers. This has led him to call for new forms of democratic development premised on reclaiming the state, redistributing wealth and income, green transformation, and sharing and reducing work. We agree. Certainly, in Uganda major democratic reforms are required to the overall political and legal system, as well as to national labour legislation, to regulate private capital and create a context where union organising can take place in safe, open, democratic and transparent conditions. However, we share the sober reflections of Andrew Brooks (2015: 248), who, in his extensive survey of labour exploitation in the global apparel industry, concludes by noting the many things that need to be done - global labour solidarity, higher wages, global redistribution of wealth - while acknowledging that such proposals may seem "politically unrealistic" given the demands of transnational capital and current global policy trajectory. He admits, "It is frustrating [to] come to terms with the reality that there are no easy answers to reconciling the relationships between the production of clothing and the persistence of poverty" (Brooks, 2015: 236).

Importantly, the gains made by informal sector organising in Uganda are significant and vital in their own right, representing crucial achievements for union organisers operating under difficult conditions while also pointing the way forward through a community unionist and LLD approach. Along these lines, our work points to: 1) the potentially significant gains that can be made from community union organising of the informal sector; 2) the barrier to such organising posed by the formal-informal divide; and 3) the need for informal union organisers to have access to stable, reliable funds and resources. For local labour organisers, a more community unionist/LLD approach could bring positive benefits - always considering, of course, the specific conditions each union must confront. The case of organised textile workers, for instance, whose gains have been essential but limited, suggests that new avenues exist to reach out to self-employed textile workers to expand the union's impact and reach, learning from examples in the transport sector. For the global labour movement, the challenge becomes how to help informal sector organisers overcome the barriers they face, the two most immediate of which (the formal-informal divide, and stable and reliable funds) can be mitigated by greater financial resources on the ground for the direct activities associated with informal sector work. Can new and creative ways be developed to assist informal sector union organisers with stable, long-term, reliable support? This could take various forms: creating new, direct partnerships between wealthier Northern unions and those in Uganda 
(new forms of union-to-union engagement); directing existing development funding (much of it currently aimed at what Selwyn would appropriately consider CCDT) toward informal union organising to enable effective, grassroots "development" efforts; or redirecting funding aimed at an education based on Western, technical and business unionist thinking toward community unionism and LLD efforts, drawing insights from the examples above and others. These are open questions and ones that are often of concern for unions globally. What Uganda's informal sector unions have revealed is the potential that exists, driven by the tireless work of union organisers under challenging social, economic and political conditions. Expanding, building, replicating and further entrenching these community unionist gains requires envisioning new forms of solidarity to contribute to overcoming the structuralist barriers that informal union organisers and workers confront and contend with every day.

\section{References}

Amin, S. (1976) Unequal Development. An Essay on the Social Formations of Peripheral Capitalism. New York: Monthly Review.

Andrae, G. and B. Beckman (2011) Trade Unions, Tailors, and Civil Society. Labour, Capital and Society, 44(1): $19-42$.

Bamber, P. and C. Staritz (2016) The Gender Dimensions of Global V alue Chains. Geneva:: International Center for Trade and Sustainable Development (ICTSD). https://ictsd.iisd.org/themes/development-andldcs/research/the-gender-dimensions-of-global-value-chains (accessed 16 May 2021).

Barrientos, S., G. Gereffi and A. Rossi (2010) Economic and Social Upgrading in Global Production Networks: Developing a Framework for Analysis. Working Paper 3: Capturing the Gains. http://www.capturingthegains.org/publications/workingpapers (accessed 12 December 2017).

Barya, J.-J. (1990) Law, State, and Working Class Organization in Uganda 1962-1987. Coventry: University of Warwick.

Berg, B. (2004) Qualitative Research Methods for the Social Sciences. Fifth edition. Boston, MA: Pearson.

Brooks, A. (2015) Clothing Poverty: The Hidden World of Fast Fashion and Second-hand Clothes. London: Zed Books.

Chen, M.A. (2012) The Informal Economy: Definitions, Theories and Policies. WIEGO Working Paper: 26. Manchester: Women in Informal Employment: Globalizing And Organizing. http://www.wiego.org/ sites/default/files/publications/files/Chen WIEGO WP1.pdf (accessed 9 January 2019).

Chen, M.A., C. Bonner and F. Carré (2015) Organizing Informal Workers. Benefits, Challenges and Successes. New York: United Nations Development Program.

Chen, M.A., J. Vanek, F. Lund, J. Heintz, C. Bonner and R. Jhabvala (2005) The Progress of the World's Women 2005. Women, Work and Poverty. New York: United Nations Development Fund for Women.

Faniel, J. (2009) Belgian Trade Unions, the Unemployed and the Growth of Unemployment. In The Politics of Unemployment in Europe: Policy Responses and Collective Action, edited by M. Guigni. Farnham: Ashgate.

Gallin, D. (2001). Propositions on Trade Unions and Informal Employment in Times of Globalisation. Malden: Blackwell Publishers.

Haller, W. and A. Portes (2005) The Informal Economy. In Handbook of Economic Sociology, edited by N. Smelser and R. Swedberg. New York: Russell Sage Foundation.

Harding, P. and R. Jenkins (1989) The Myth of the Hidden Economy. Towards a New Understanding of Informal Economic Activity. Philadelphia, PA: Open University Press.

Hussmanns, R. (2004) Defining and Measuring the Informal Economy. Geneva: ILO.

Hyman, R. (2001) Understanding European Trade Unionism. Between Market, Class and Society. London: Sage. 
International Federation of Professional and Technical Engineers (IFPTE) (2019) Union Q $\mho A$. Definitions and Union Jargon. http://www.ifpte.org/join-us/questions-answers (accessed 16 October 2019).

International Labour Organization (ILO) (2002) The Informal Sector in Sub-Saharan Africa. Working Paper on the Informal Economy. Geneva: ILO.

International Labour Organization (ILO) (2018) Women and Men in the Informal Economy. A Statistical Picture. Third edition. Geneva: ILO.

International Labour Organization (ILO) (2019) Decent Work. https://www.ilo.org/global/topics Ldecent-work/lang--en/index.html (accessed 16 October 2019).

International Trade Union Confederation (ITUC) (2012) Annual Survey of Violations of Trade Union Rights Uganda. https://www.refworld.org/docid/4fd8891dc.html (accessed 16 October 2019).

Leuenberger, H. and R. Bachofen (2008) Pollution Menacing Lake Viktoria. Quantification of Point Sources and Jinja Town, Uganda. Water SA, 34(1): 89-98.

Lindbeck, A. and D. Snower (2001) Insiders versus Outsiders. The Journal of Economic Perspectives, 15(1): 165188.

Lindell, I. (2011) Introduction to the Special Issue. Organizing Across the Formal-informal Worker Constituencies. Labour, Capital and Society, 44(1): 3-16.

Linders, A. and M. Kalander (2010) A Precarious Balance of Interests: Unions and the Unemployed in Europe. In The Contentious Politics of Unemployment in Europe, edited by M. Giugni. New York: Palgrave.

Marx, K. (1867 [2010]). Das Kapital. Marx \& Engels Collected Works, 35. London: Lawrence \& Wishart.

Mayer, F. and J. Pickles (2010) Re-embedding Governance: Global Apparel V alue Chains and Decent Work. Working Paper 1: Capturing the Gains. http://www.capturingthegains.org/publications/working papers (accessed 12 December 2017).

Milberg, W. and D. Winkler (2010) Economic and Social Upgrading in Global Production Networks: Problems of Theory and Measurement. Working Paper 4: Capturing the Gains. http://www.capturingthegains.org Lpublications/workingpapers (accessed 12 December 2017).

Mosoetsa, S. (2001) The Manchester Road. Women and the Informalization of Work in South Africa's Footwear Industry. Labour, Capital and Society, 34(2): 185-206.

Pearson, R. (2004) Organising Home-Based Workers in the Global Economy: An Action-Research Approach. Development in Practice, 14(1/2): 136-148.

Portes, A. and S. Sassen-Koob (1987) Making it Underground: Comparative Material on the Informal Sector in Western Market Economies. American Journal of Sociology, 93(1): 30-61.

Rosnick, D., M. Weisbrot and J. Wilson (2017) The Scorecard on Development, 1960-2016: China and the Global Economic Rebound. Washington, DC: Center for Economic and Policy Research (CEPR). http://cepr.net/images/stories/reports/scorecard-2017-10.pdf (accessed 16 May 2021).

Schurman, S. and A. Eaton (2013) The Transformation of Work. Challenges and Strategies of Trade Union Organising in the Informal Sector. Washington, DC: Solidarity Centre.

Selwyn, B. (2014) The Global Development Crisis. Cambridge, UK: Polity Press.

Selwyn, B. (2017) The Struggle for Development. Cambridge, UK: Polity Press.

Sehnbruch, K., B. Burchell, N. Agloni and A. Piasna (2015) Human Development and Decent Work. Why Some Concepts Succeed and Others Fail to make an Impact. Development and Change, 46(2): 197-224.

Spooner, D. and J.M. Mwanika (2016) Trade Unions in Transformation. Kampala: Friedrich Ebert Foundation.

Standing, G. (1997) Globalization, Labour, Flexibility and Insecurity. The Era of Market Regulation. European Journal of Industrial Relations, 3(1): 7-37.

Swaminathan, M. (1991) Understanding the Informal Sector: A Survey. Cambridge, MA: MIT University Press. 
Ulandssekretariatet (2016) Labour Market Profile. Uganda. Copenhagen: LO/FTF Council Analytical Unit/Ulandssekretariatet.

Verick, S. (2006). The Impact of Globalization on the Informal Sector in Africa. Addis Ababa: United Nations Economic Commission for Africa.

\section{ACKNOWLEDGEMENTS}

The authors would like to thank the anonymous reviewers and editors of the Global Labour Journal, Kate Ervine, Maher el Shaar, the team at the Friedrich Ebert Stiftung Uganda around John Bosco Mubiru and Mareike Le Pelly, as well as Stephen Odaro, Namusabi Rebecca, Irene Faith and John Mark Mwanika for their advice and encouragement. Gavin would like to thank the Canada Research Chairs programme [grant number 950-231376]. We also want to thank the committee members that oversaw the thesis related to this research: David Black, Catherine Conrad and Rohini Bannerjee.

\section{BIOGRPAHICAL NOTES}

GAVIN FRIDELL is Canada Research Chair in International Development Studies at Saint Mary's University in Halifax, and the author of numerous books and articles on fair trade and free trade, including his latest book Coffee (Polity Press, 2014). He is a member of the College of New Scholars of the Royal Society of Canada and is on the Advisory Board of the Canadian Fair Trade Network (CFTN). His latest research explores the political economy and the ideological politics of global trade, with a focus on North America and the Caribbean. [Email: gavin.fridell@smu.ca]

TOBIAS GERHARD SCHMINKE holds a Master of Arts in International Development Studies from Saint Mary's University. In 2020, he received the Governor General's Gold Medal for his thesis work on trade unionism in the informal economy in Uganda. [Email: tobias.schminke@gmail.com] 